\title{
Monocotyledon fossil leaf from the Early Cretaceous of India
}

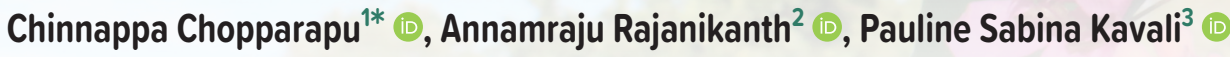 \\ and Sarah Gonçalves Duarte ${ }^{4}$ (])
}

Received: December 29, 2020

Accepted: April 16, 2021

\begin{abstract}
Reports of the angiosperm macrofossils from the Early Cretaceous sediments of India are relatively poor, with only one report from the Krishna-Godavari Basin. The present study documents a monocotyledon leaf fossil from the Barremian-Aptian (Early Cretaceous) of Gangapur Formation, Pranhita-Godavari Basin, India. The present fossil leaf placed under a new genus Sahniophyllum and it is characterised by the ribbon shaped leaves, with parallel venation, arranged in rosette form suggests its probable affinity with Hydrocharitaceae. The taphocoenosis demonstrates its autochthonous preservation and aquatic habitat.
\end{abstract}

Keywords: Angiosperm, Early Cretaceous, Gangapur Formation, India, Monocot, Sahniophyllumindica gen. et sp. nov.

\section{Introduction}

The early origin and evolution of the Angiosperms is Darwin's abominable mystery (Friedman 2009). However, it is well established that the flowering plants became a part of the global ecosystem by the Early Cretaceous (Hughes 1994; Bell et al. 2010; Friis et al. 2011). Currently, the angiosperms are the major group of land plants with more than 300.000 species and share $89.4 \%$ among embryophytes (Cronquist 1981; Crepet 2000). Modern monocots are composed of 81 families and about 60.000 species. Their origin and rapid explosion is still under debate (Doyle 2006; 2012 and references therein) but they became the significant components of the ecosystem from the Cretaceous (Friis et al. 2011).They changed the face of earth ecosystem and provided the structural definition for most terrestrial ecosystems (Crepet 2000; Graham 2011). The diversification of this group also assisted in the explosion of the ferns
(Schneider et al. 2004) and co-evolution of the insects (Grimaldi \& Engel 2005).

The angiosperms mega fossils from the Early Cretaceous sediments were well documented from the various parts of the globe (Hickey \& Doyle 1977; Hill 1994; Sun et al. 1998; Taylor et al. 2009; Friis et al. 2011). However, the mega fossils of angiosperms from the Early Cretaceous sedimentary basins of India were poorly known (Chinnappa et al. 2020b). The previous reports of the fossils described under the angiosperms (Sahni 1932; Sharma 1997; Banerji 2000) were later proved to be Bennettitaleans (Bose \& Sah 1954; Srivastava \& Krassilov 2012). The lack of early angiosperm remains from the Early Cretaceous sedimentary basins of India hinders understanding of their early evolutionary history locally and globally. In India, the existing knowledge of angiosperm history is based on the fossils from the upper part of the Cretaceous when this group diversified (Crane et al. 2000; Soltis \& Soltis 2004; Crepet 2007; Friis et al. 2011).

1 Department of Botany, Andhra Loyola College, 520-008, Vijayawad, Andhra Pradesh, India

2 Ushodaya Apartments, 500-017, Tarnaka, Hyderabad, India

3 Birbal Sahni Institute of Palaeosciences, 226-020, Lucknow, Uttar Pradesh, India

4 Departamento de Solo, Instituto de Agronomia, Universidade Federal Rural do Rio de Janeiro,23890-000, Seropedica, RJ, Brazil

* Corresponding author: chinnabsip@gmail.com 
The present study describes a monocotyledon mega fossil from the Barremian-Aptian of Gangapur Formation, Pranhita-Godavari (PG) Basin, East Coast of India.

\section{Materials and methods}

\section{Geological setting}

The Pranhita-Godavari Basin is one of the largest Gondwana basins of India. It contains an almost complete succession of Gondwana rocks. The sediment in the basin deposited from the Late Carboniferous/Early Permian to Cretaceous, is ca $3000 \mathrm{~m}$ thick (Biswas 2003). Sedimentation in the Gangapur area took place during the Early Cretaceous after renewed rift activity (Biswas 2003). The Gangapur Formation is $100-250 \mathrm{~m}$ thick, and the Chikyala Formation is ca 275 m (Lakshminarayana 1996). The Gangapur Formation is sandwiched between the lower Kota Formation which is of Jurassic age and is well known for its mammalian fossils (Parmar et al. 2013) and upper Deccan traps. The Formation is characterized by coarse ferruginous sandstone with many pebble bands succeeded by an alternating sequence of sandstones and mudstones or silty mudstone with abundant fossil plant material. Sedimentological and heavy mineral studies indicated that formation was deposited under freshwater conditions (Ramamohanarao et al. 2003). The Gangapur Formation is dated as Barremian-Aptian in age based on palaeobotanical evidence (Chinnappa et al. 2020a and references therein).

\section{Data collection and analysis}

Sahniophyllum indica gen. et sp. nov. was collected from the mudstone sequences of Gangapur Formation, PranhitaGodavari Basin exposed on the banks of ButarmalNala $\left(19^{\circ} 27^{\prime} \mathrm{N}\right.$; $\left.79^{\circ} 13^{\prime} \mathrm{E}\right)$ about $13 \mathrm{~km}$ West North West of the Asifabad (19 ${ }^{\circ} 21^{\prime}$ N-79 $17^{\circ}$ E) Adilabad District, Telangana State, India (Figs. 1, 2). This taxon is fairly preserved as an impression with most morphological details on pinkishgray colored mudstone. Counterparts of the impression were collected and studied. On the same slab, our taxon cooccurs with the fragments of Elatocladus and unknown seed impression. We follow the Angiosperm Phylogeny Group (APG III 2009) to classify the fossil. The fossil specimens with id number BSIP 40427 and 40428 were hosted in a repository of Birbal Sahni Institute of Palaeosciences, India.

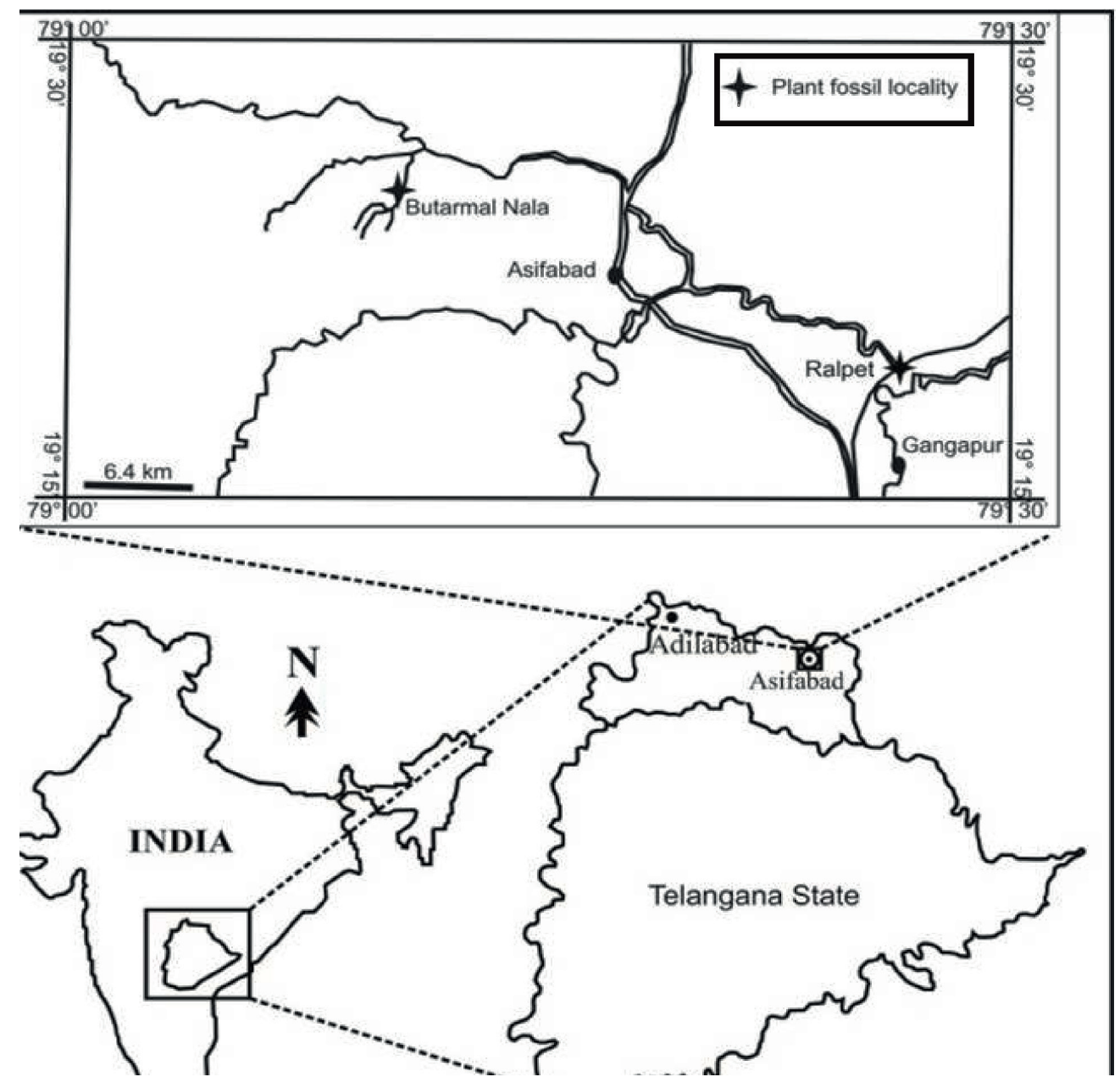

Figure 1. Map showing the studied area and the place where plant fossil was found. 


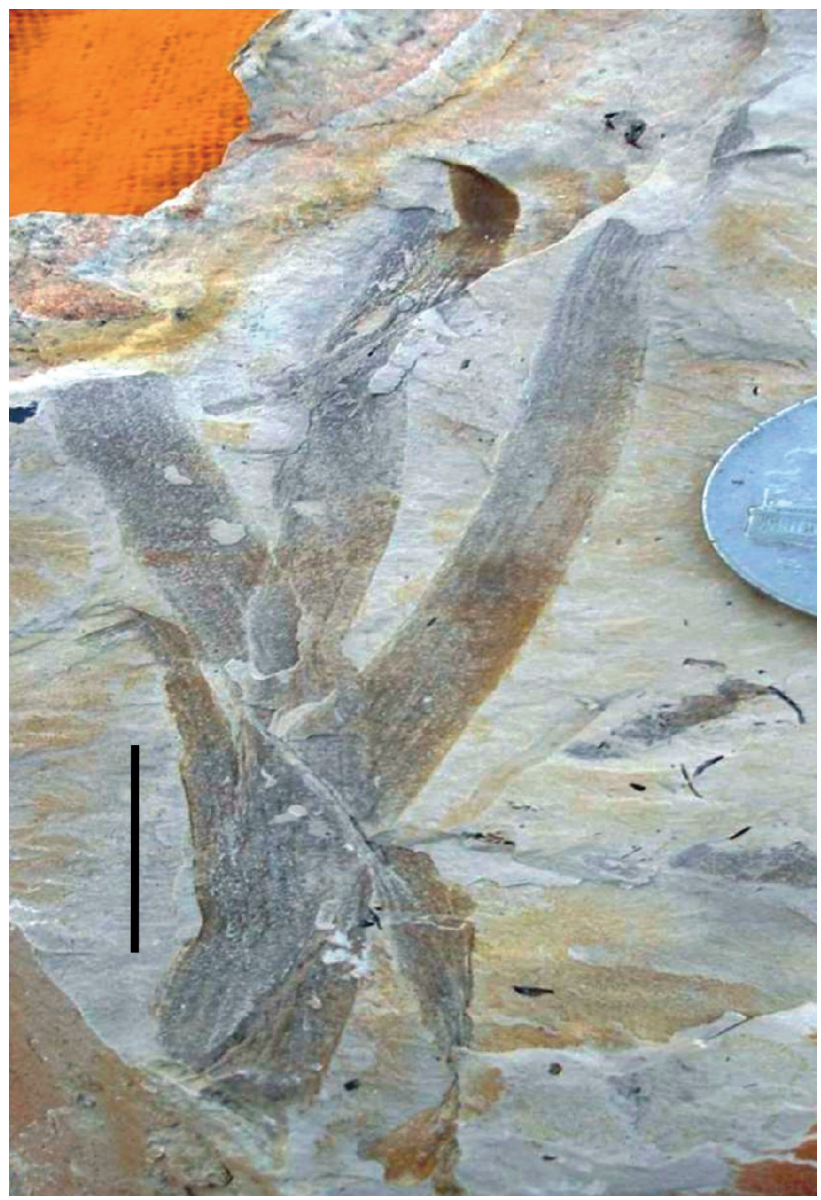

Figure 2. Photo showing the plant fossil.

Attempts to find pollen and cuticles by macerating small pieces of the same slab failed. Fossils were studied with an Olympus SZH 10 stereo dissecting microscope and photographed with a Canon SX 150 IS digital camera using either polarized light or low angle lighting to reveal surface details.

\section{Results}

\section{Systematic palaeontology}

Family Hydrocharitaceae Juss.

Genus Sahniophyllum Chinnappa \& Rajanikanth gen. nov.

Generic diagnosis. The fossil consists of a cluster of five leaves arranged in a rosette form on short corm-like shoot. The leaf is sessile and ribbon/strap shaped. Margin is entire. Leaf width is mostly constant up to the upper part, 7-8 $\mathrm{mm}$ and maximum available length is $110 \mathrm{~mm}$ (may exceed up to $200-300 \mathrm{~mm}$ ). Venation is parallel, five to six primary veins with hierarchical veins in between and all veins converge towards the leaf apex.

Etymology: Sahnio is given in honor of the renowned palaeobotanist Birbal Sahni; Phyllum for leaves.

Sahniophyllum indica Chinnappa \& Rajanikanth sp. nov.

Figures 2, 3, 4

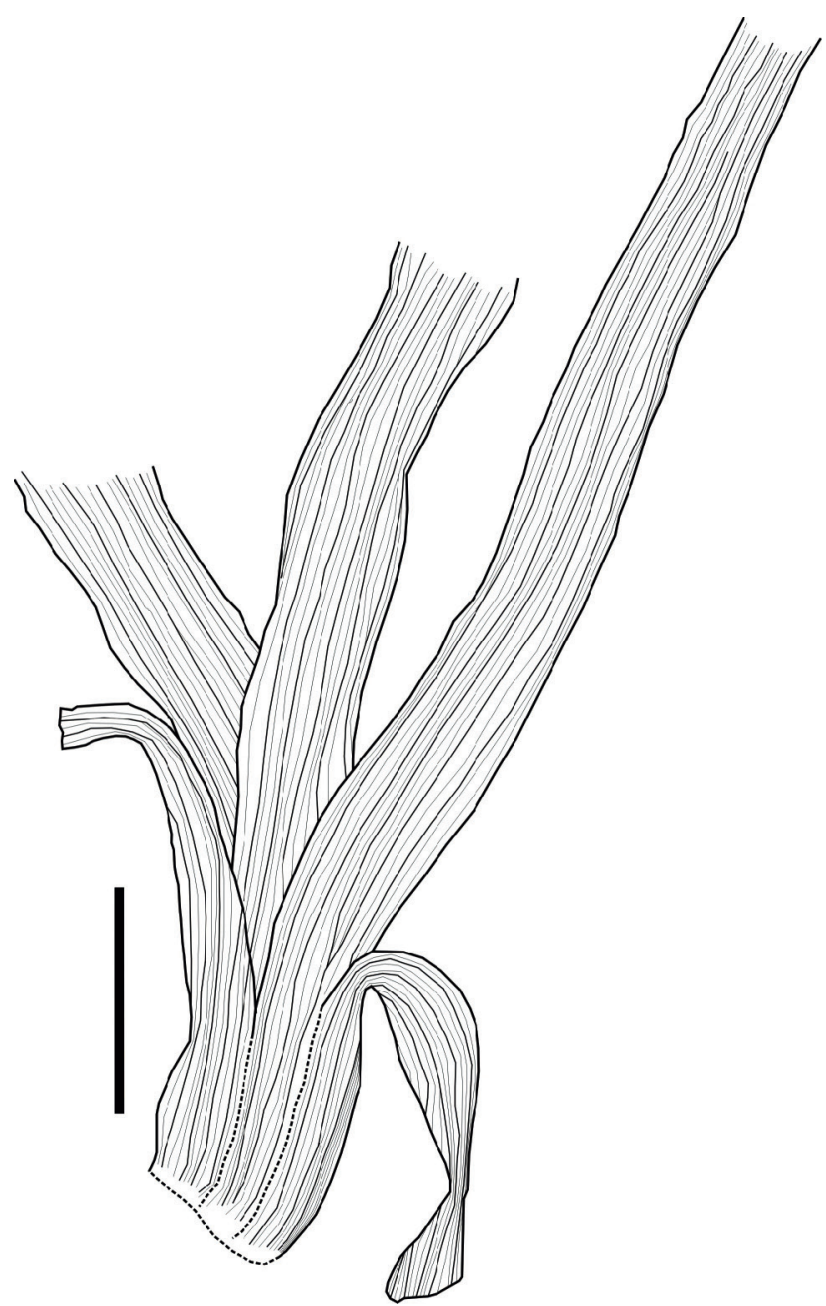

Figure 3. Illustration with the reconstruction of the plant fossil.

Etymology: indica is given after India from the country where it is known.

Type material. BSIP 40427

Referred specimens. BSIP 40427, 40428

Specific diagnosis. The specific diagnosis is the same as for the generic diagnosis due to the limited material available currently.

Geographic occurrence. On the banks of Butarmal Nala $13 \mathrm{~km}$ North West of the Asifabad, Adilabad District, Telangana State, India

Stratigraphic occurrence. Barremian-Aptian, Gangapur Formation, Pranhita-Godavari Basin.

Description. A vegetative plant body preserved most of the details of herbaceous pattern with possible dimorphic 
shoot consisting of horizontal stolons and vertical short corm, up on which rosette leaves are born (Figs. 2, 3 and also see Fig. 4 for a reconstruction). Five leaves of entire margin are present on the short corm like shoot, 7-8 $\mathrm{mm}$ wide, $110 \mathrm{~mm}$ long (maximum available). Base and apex of the leaf are unknown. Venation is parallel and five to six primary veins converge from leaf base to apex. Second order veins visible as finer longitudinal strands between the denser primary veins. Cross veins not observed. No reproductive features are known.

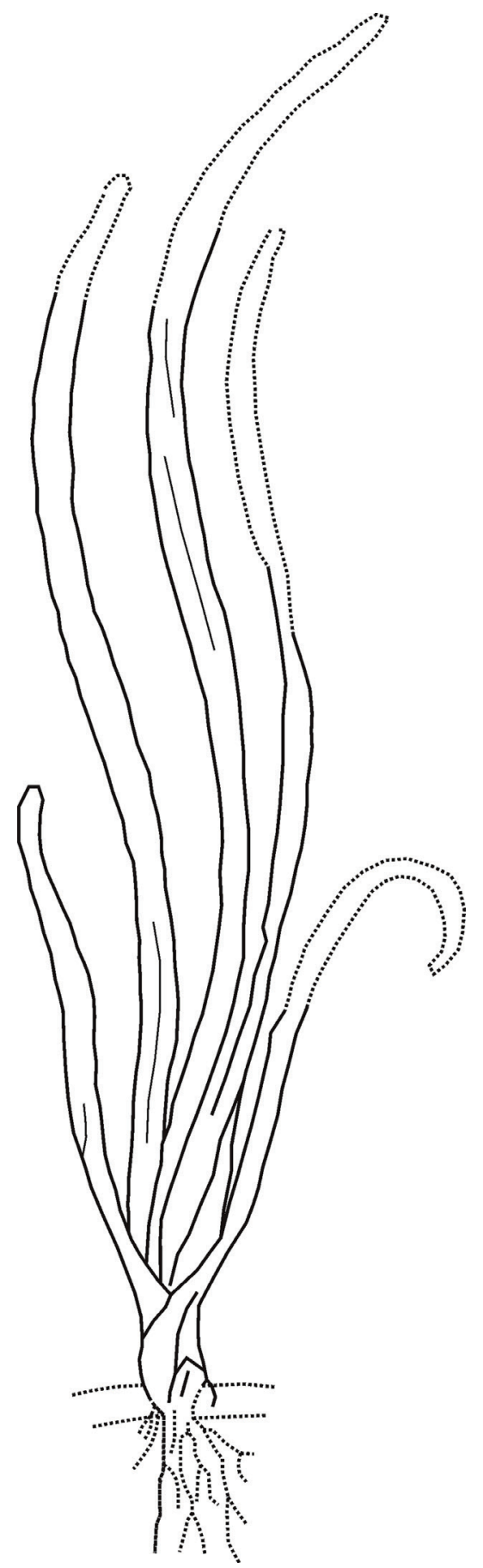

Figure 4. Illustration with the reconstruction of the plant fossil.
Remarks. The evidence allows us to hypothesize that leaves are sessile, not obviously distichous and leaf apex is bluntly obtuse. Even though the maximum available leaf size is $110 \mathrm{~mm}$, it is likely longer ranging up $200 \mathrm{~mm}$ due base and apex are not preserved.

Comparison. The fossil plant described herein resembles various Hydrocharitaceae in its habit (Fig. 4) especially with the extant Vallisneria. Hydrocharitaceae (Alismatales) is a fully-aquatic monocot family, consisting of 18 genera and approximately 120 species (Les et al. 2006). Several genera of the Hydrocharitaceae (e.g., Ottelia, Blyxa) show similar habit, varying slightly in the arrangement of leaves, venation and habitat. So far, leaves of a single specimen of the fossil Vallisneria ( $V$. janecekii Bogner \& Kvaček) from the Early Miocene of the Most Basin (North Bohemia), Czech Republic, are documented (Bogner \& Kvaček 2009). The leaves of $S$. indica gen. et sp. nov. are very similar to $V$. janecekii in many characters, like leaf size, entire margin and venation (for instance, the absence of transverse veins). However, in $V$. janecekiithe development of stolon is well established. Because of the greatest similarity of $S$. indica gen.et sp. nov., with extant genera of the Hydrocharitaceae, our taxon might be an extinct form of the lineage of this extant family.

\section{Discussion}

\section{Evolutionary significance of the Sahniophyllum indicagen. et sp. nov.}

The early fossil history of monocots is a subject of dispute (Doyle 1973; Gandolfo et al. 2000; Friis et al.2004; 2010; 2011; Hofmann \& Zetter 2010) and their report from the Early Cretaceous is uncertain (Gandolfo et al. 1998, 2000). However, recent studies establish their existence during the Early Cretaceous (Coiffard et al. 2019; Liu et al. 2020). Molecular phylogeny studies (Bremer 2000; Janssen \& Bremer 2004; Kato et al. 2003; Chen et al. 2012) suggested the presence of Alismatales during the Early Cretaceous. The present study also supports the evolution of Monocots early in the Cretaceous and their rapid diversification in the Late Cretaceous.

Molecular diverging date derived from sequences of chloroplast protein coding genes and nuclear rRNA genes14 and mitochondrial protein coding genes (Laroche et al. 1995) suggest the Jurassic ( 200 Mya) to be the most likely time for the early divergence between monocots and dicots. Recent multi-gene analysis by Hedges et al. (2006) also supports the Jurassic age yet slightly younger than the previous studies ( 130-150 Mya). Molecular phylogeny studies of Bremer (2000), Wikström et al. (2001), Janssen \& Bremer (2004) clearly demonstrated that much of the monocot diversification took place before 100 Mya during the Early Cretaceous. These studies indicate, with few 
exceptions, that most family stem lineages were present by the end of the Cretaceous, however, reliable fossils related to any taxonomic rank of the monocots are largely unknown earlier than the late Cretaceous (Gandolfo 1998; Friis et al. 2011). The under-representation of the monocots in the fossil record can be attributable to their physiological properties (Herendeen \& Crane 1995). This created a large gap between the molecular and palaeobotanical evidence. In this sense, molecular phylogeny studies (Bremer 2000; Janssen \& Bremer 2004; Kato et al. 2003; Chen et al. 2012) suggested the presence of Alismatales during the Early Cretaceous, and our specimen provides the evidence and helps to bridge this gap.

The divergence time for Hydrocharitaceae is still subject of dispute; two competing ages have resulted in molecular phylogeny. The age estimates for the Hydrocharitaceae by Jansen \& Bremer (2004) and Chen et al. (2012) are 75-88 Mya and 54.7-72.6 Ma respectively (i.e., Palaeocene-Late Cretaceous). However, Kato et al. (2003) dated the Hydrocharitaceae as $119 \pm 11 \mathrm{Ma}$ (i.e., latest Early Cretaceous). The report of Sahniophyllum indica gen. et sp. nov., of possible Hydrocharitaceae affinity, alert to revisit dating of the family with a great concern. This record represents the first unequivocal presence of Alismatales during the Early Cretaceous and it should be considered as a forerunner in Hydrocharitaceae members. So, little is known about the Early Cretaceous monocot fossil record, therefore, each fossil that can be placed in this clade provides new and important information to improve the lineage of this group in the angiosperm evolution.

\section{Ecological aspects}

Taphonomy has played a major role in understanding fossil preservation and their subsequent interpretations (Behrensmeyer et al. 1992). The whole plant body is rarely recovered (Sun et al. 2011; Liu et al. 2020) and such type of plant preservation is common in not or minimum transported deposits. Sahniophyllum indica gen. et sp. nov. is preserved almost complete thereby indicating minimum transportation before it is buried. The incompleteness of our fossil material was caused by sampling conditions. The available evidence of Sahniophyllum indica gen. et sp. nov. demonstrate that the plant was probably a submerged small herb of 200-300 mm height, with dimorphic shoot and might be growing in a standing water body. Leaves were usually born on reduced corm like short shoot (Fig. 4). Eventually at maturity the plant got detached from runners/stolons along with the corm like short shoot and buried without much transportation. Intact leaves of $S$. indica gen. et sp. nov., reinforced in situ autochthonous preservation (Ferguson 1985; Behrensmeyer et al. 1992). Ecologically, the early angiosperms were considered herbs with aquatic habitat preferences (Taylor \& Hickey 1992; Sun et al. 2002).

\section{Conclusion}

The present finding of Sahniophyllum gen. nov. represents a first angiosperm macro fossil record from India that can be definitely assigned to the Monocots. The characteristic features of the leaves suggest a probable affinity to the family Hydrocharitaceae. Given its nature of leaves and mode of preservation, the plant would have grown in the shallow parts of the water body.

\section{Acknowledgements}

The authors are grateful to Dr Vandana Prasad, Director, Birbal Sahni Institute of Palaeobotany, Lucknow for encouragement and providing infra-structural facilities. We are also grateful to Dr Christopher Cleal, Natural Sciences National Museum Cardiff, for constructive suggestions and language editing. We are indeed thankful to the anonymous reviewer for constructive suggestions.

\section{References}

APG III - Angiosperm Phylogeny Group III. 2009. An update of the Angiosperm Phylogeny Group classification for the orders and families of flowering plants: APG III. Botanical Journal of the Linnean Society 161: 105-121.

Banerji J. 2000. Occurrence of angiosperm remains in an Early Cretaceous intertrappean bed, Rajmahal Basin, India. Cretaceous Research 21: 781-784.

Behrensmeyer AK, Damuth JD, DiMichele WA, Potts R, Sues HD, Wing SL. 1992. Terrestrial Ecosystems through Time. Chicago, The University of Chicago Press.

Bell CD, Soltis DE, Soltis PS. 2010. The age and diversification of the angiosperms re-revisited. American Journal of Botany 97: 1296-1303.

Biswas SK. 2003. Regional tectonic framework of the Pranhita-Godavari Basin, India. Journal of Asian Earth Sciences 21: 543-551.

Bogner J, Kvaček ZA. 2009. Fossil Vallisneria plant (Hydrocharitaceae) from the Early Miocene freshwater deposits of the Most Basin (North Bohemia). Aquatic Botany 90: 119-123.

Bose MN, Sah SCD. 1954. On Sahnioxylon rajmahalense, a new name for Homoxylon rajmahalense Sahni, and S. andrewsii, a new species of Sahnioxylon from Amrapara in the Rajmahal Hills, Bihar. Palaeobotanist 3: 1-8.

Bremer K. 2000. Early Cretaceous lineages of monocot flowering plants. Proceedings of the National Academy of Sciences 97: 4707-4711.

Chen LY, Chen JM, Gituru RW, Wang QF. 2012. Generic phylogeny, historical biogeography and character evolution of the cosmopolitan aquatic plant family Hydrocharitaceae. BMC Evolutionary Biology 12: 1-30.

Chinnappa C, Kavali PS, Rajanikanth A, Pasquo M, Bernardes-deOliveira MEC. 2020a. Early Cretaceous flora from the east coast sedimentary basins of India: their chronostratigraphic and palaeobiogeographic significance. In: Banerjee S, Sarkar S. (eds.) Mesozoic stratigraphy of India- A multi-proxy approach. Cham, Springer.

Chinnappa C, Rajanikanth A, Kavali PS, Duarte SG. 2020b.Angiosperms from the Early Cretaceous sediments of India. Revista do Instituto de Geociências - USP 20: 123-136.

Coiffard C, Kardjilov N, Manke I, Bernardes-de-Oliveira ME. 2019. Fossil evidence of core monocots in the Early Cretaceous. Nature Plants 5: 691-696. 
Crane PR, Friis EM, Pedersen KR. 2000. The origin and early diversification of angiosperms. In: Gee H. (ed.) Shaking the Tree: Readings from Nature in the History of Life. Chicago, The University of Chicago Press. p. 233-250.

Crepet WL. 2000. Progress in understanding angiosperm history, success, and relationships: Darwin's abominably "perplexing phenomenon". Proceedings of the National Academy of Sciences 97: 12939-12941.

CrepetWL. 2007. Origin and Diversification of Angiosperms. https://enviro2. doe.gov.my/ekmc/wp-content/uploads/2016/08/1385458173-3-s2.0B9780122268656005146-main.pdf.

Cronquist A. 1981. An integrated system of classification of flowering plants. New York, Columbia University Press.

Doyle JA. 1973. Fossil evidence on early evolution of the monocotyledons. Quarterly Review of Biology48: 399-413.

Doyle JA. 2006. Seed ferns and the origin of angiosperms. Journal of the Torrey Botanical Society 133: 169-209.

Doyle JA. 2012. Molecular and fossil evidence on the origin of angiosperms. Annual Review of Earth and Planetary Sciences 40: 301-326.

Ferguson DK. 1985. The origin of leaf-assemblages—new light on an old problem. Review of Palaeobotany and Palynology 46: 539-559.

Friedman WE. 2009. The meaning of Darwin's "abominable mystery". American Journal of Botany 96: 5-21.

Friis EM, Crane PR, Pedersen KR. 2011. Early Flowers and Angiosperm Evolution. Cambridge, Cambridge University Press.

Friis EM, Pedersen KR, Crane PR. 2004. Araceae from the Early Cretaceous of Portugal: Evidence on the emergence of monocotyledons. Proceedings of the National Academy of Sciences 101: 16565-16570.

Friis EM, Pedersen KR, Crane PR. 2010. Diversity in obscurity: fossil flowers and the early history of angiosperms. Philosophical Transactions of the Royal Society B: Biological Sciences 365: 369-382.

Gandolfo MA, Nixon KC, Crepet WL, Stevenson DW, Friis EM. 1998. Oldest known fossils of monocotyledons. Nature 394: 532-533.

Gandolfo MA, Nixon KC, Crepet WL. 2000. Monocotyledons: a review of their Early Cretaceous record. In: Wilson KL, Morrison DA. (eds.) Monocots: systematics and evolution. Melbourne, Commonwealth Scientific and Industrial Research Organisation - CSIRO. p. 44-52.

Graham A. 2011. The age and diversification of terrestrial New World ecosystems through Cretaceous and Cenozoic time. American Journal of Botany 98: 336-351.

Grimaldi D, Engel MS. 2005. Evolution of the Insects. New York, Cambridge University Press.

Hedges SB, Dudley J, Kumar S. 2006. Time Tree: a public knowledge-base of divergence times among organisms. Bioinformatics 22: 2971-2972.

Herendeen PS, Crane PR. 1995. The fossil history of the monocotyledons. In: Rudall PJ, Cribb PJ, Cutler DF, Humphries CJ. (eds.) Monocotyledons: Systematics and Evolution. Kew, Royal Botanic Gardens. p. 1-21.

Hickey LJ, Doyle JA. 1977. Early Cretaceous fossil evidence for angiosperm evolution. Botanical Review 43: 3-104.

Hill RS. 1994. History of the Australian vegetation: Cretaceous to Recent. Adelaide, University of Adelaide Press.

Hofmann CC, Zetter R. 2010. Upper Cretaceous sulcate pollen from the Timerdyakh Formation, Vilui Basin (Siberia). Granai 49: 170-193.
Hughes NF. 1994. The enigma of angiosperm origins. New York, Cambridge University Press.

Janssen T, Bremer K. 2004. The age of major monocot groups inferred from $800+r b c L$ sequences. Botanical Journal of the Linnean Society 146: 385-398.

Kato Y, Aioi K, Omori Y, Takahata N, Satta Y. 2003. Phylogenetic analyses of Zostera species based on $\mathrm{rbcL}$ and matK nucleotide sequences: implications for the origin and diversification of seagrasses in Japanese waters. Genes and Genetic Systems 78: 329-342.

Lakshminarayana G. 1996. Stratigraphy and structural framework of the Gondwana sediments in the Pranhita-Godavari Valley, Andhra Pradesh. Gondwana Nine 1: 311-330.

Laroche J, Peng L, Bousquet J. 1995. Mitochondrial DNA and monocotdicot divergence time. Molecular Biology and Evolution 12: 1151-1156.

Les DH, Moody ML, Soros CL. 2006. A reappraisal of phylogenetic relationships in the monocotyledon family Hydrocharitaceae (Alismatidae). Aliso 22: 211-230.

Liu ZJ, Chen LJ, Wang X. 2020. A whole-plant monocot from the Lower Cretaceous. Palaeoworld 30: 169-175.

Parmar V, Prasad GV, Kumar D. 2013. The first multituberculate mammal from India. Naturwissenschaften 100: 515-523.

Ramamohanarao T, Sairam K, Venkateswararao B, Nagamalleswararao K, Viswanath K. 2003. Sedimentological characteristics and depositional environment of Upper Gondwana rocks in the Chintalapudi sub-basin of the Godavari Valley, Andhra Pradesh, India. Journal of Asian Earth Sciences 21: 691-703.

Sahni B. 1932. Homoxylonrajmahalense gen. et sp. nov., a fossil angiospermous wood, devoid of vessels, from the Rajmahal hills, Bihar. Memoirs of the Geological Survey of India 20: 1-19.

Schneider H, Schuettpelz E, Pryer KM, Cranfill R, Magallón S, Lupia R. 2004. Ferns diversified in the shadow of angiosperms. Nature 428: 553-557.

Sharma BD. 1997. An early angiosperm fructification resembling Lesqueria Crane\&Dilcher from the Rajmahal hills, India. Phytomorphology 47: 305-310

Soltis PS, Soltis DE. 2004. The origin and diversification of angiosperms. American Journal of Botany 91: 1614-1626.

Srivastava R, Krassilov VA. 2012. Revision of Early Cretaceous angiosperm remains from the Rajmahal Basin, India, with notes on the palaeoecology of the Pentoxylon plant. Cretaceous Research 33: 66-71.

Sun G, Dilcher DL, Wang H, Chen ZA. 2011. Eudicot from the Early Cretaceous of China. Nature 471: 625-628.

Sun G, Dilcher DL, Zheng S, Zhou Z. 1998. In search of the first flower: a Jurassic angiosperm, Archaefructus, from northeast China. Science 282: 1692-1695

Sun G, Ji Q, Dilcher DL, Zheng S, Nixon KC, Wang X. 2002. Archaefructaceae, a new basal angiosperm family. Science 296: 899-904.

Taylor EL, Taylor TN, Krings M. 2009. Paleobotany: the biology and evolution of fossil plants. New York, Academic Press.

Taylor DW, Hickey LJ. 1992. Phylogenetic evidence for the herbaceous origin of angiosperms. Plant Systematics and Evolution 180:137-56.

Wikström N, Savolainen V, Chase MW. 2001. Evolution of the angiosperms: calibrating the family tree. Proceedings of the Royal Society B: Biological Sciences 268: 2211-2220. 